\section{Changes at CMAJ}

In a conference call on Monday morning, Feb. 29, 2016, members of CMAJ's Journal Oversight Committee (JOC) were informed that the editorin-chief (EIC) had been relieved of duty and the JOC itself disbanded all in direct contravention of processes the CMA had put in place to protect editorial independence, and repeatedly reaffirmed. ${ }^{1}$

Indeed, a central article of the terms of reference of the JOC reads as follows: ${ }^{2}$

The EIC can only be dismissed with a $2 / 3$ majority vote of the CMA Board having first sought the advice of the JOC. ${ }^{2}$

By summarily terminating the employ of the EIC and simultaneously disbanding JOC, the CMA has efficiently circumvented and ignored its own due process.

Almost a decade earlier, when CMAJ Editor John Hoey was dismissed (exposing the CMA to worldwide criticism), the prominent jurist Richard Pound chaired a committee that recommended governance mechanisms to ensure editorial independence of the CMAJ and any future editors. A key recommendation was the creation of a journal oversight committee to act as a buffer between editor and owner: ${ }^{3}$

The Panel recommends that a Journal Oversight Committee ... be used to resolve issues that may arise ... between the EIC and the Owner or Publisher of the CMAJ. Issues that cannot be resolved by the JOC shall be determined by the CMA Board, having considered and afforded deference to the recommendations made by the JOC. ${ }^{3}$

CMAJ's oversight committee included outside experts in research, journal editing, practice, peer review and journalism: a former editor of the New England Journal of Medicine, an original member of the Pound Commission, a member from the research community, a professor of journalism and a practising generalist physician - a cross-section of experience on which the EIC could rely for support, criticism and direction.

Over the past 2 years, the JOC has been warning the CMA of the dangers inherent in making CMAJ and its EIC primarily accountable to the newly minted business arm of the CMA, currently referred to as NewCo, and to its chief executive officer. Current events confirm how dysfunctional this forced marriage had become, and how true is the old saw that those who do not learn from history will be forced to relive it.

The JOC was not consulted about the impending dismissal, a clear abuse of process and of the terms under which its members had agreed to serve. It was a shocking breach of faith with the JOC that utterly disregarded the governance provisions of the Pound report, which had been accepted by the CMA. In an Orwellian piece of logic, the CMA, having summarily dismissed the editor and the committee put in place to protect editorial independence, then asserted that it was strengthening and reaffirming editorial independence: in a news release, it disingenuously impugned the quality of the CMAJ, pledging to create a world-class journal, which, it implied, the $C M A J$, despite all evidence to the contrary, was not. ${ }^{4}$ Equally disingenuously, it suggested that one of the reasons for the decision was the decline in submissions and citations - a complex issue that had its roots in a variety of factors, most of which predated the current EIC's time in office.

There is an irony here. So successful were the recommendations of the Pound report that they were adopted beyond our borders, most notably by the Journal of the American Medical Association, whose protections for its editor are now stronger than those extant at the CMA.

The JOC believes CMA members have been badly served by this set of decisions, which turn the clock back to the turmoil and questionable Board practices that led to the creation of the JOC nearly a decade ago.

The absence, going forward, of independent oversight at the journal leaves it, and its next editor, exposed to the pressures of profitability. Such pressures can affect editorial independence in a myriad of subtle, and not so subtle ways, and would have no forum for objective review. CMA members should be concerned. They had a world-class journal. What remains?

\section{John Wootton MD}

Society of Rural Physicians of Canada, Shawville, Ont.

Jerome Kassirer MD

Wellesley, Mass.

\section{Eldon Smith MD}

University of Calgary, Calgary, Alta.

Céline Huot MD

CHU Sainte-Justine Research Centre,

Montréal, Que.

Elly Alboim BA, MSc

Earnscliffe Strategy Group, Ottawa, Ont.

Until recently, John Wootton was Chair of CMAJ's Journal Oversight Committee (JOC). The other signatories to this letter were also members of the JOC.

\section{References}

1. Kelsall D, Patrick K, Stanbrook MB, et al. Upholding the integrity of your CMAJ. CMAJ 2016;188:397.

2. Working Group on Governance and Accountability of the CMAJ. 2014. Available: www.cmaj.ca/site/ pdfs/Report-Governance-Accountability-CMAJ. pdf (accessed 2016 Mar. 7)

3. CMAJ Governance Review Panel. Final Report Available: www.cmaj.ca/site/pdfs/GovernanceRe viewPanel.pdf (accessed 2016 Mar. 7).

4. CMA Board of Directors announces restructuring and modernization plan for CMAJ. Available: www.cma.ca/En/Pages/cma-board-of-directorsannounces-restructuring-and-modernization-planfor-the-cma-journal.aspx (accessed 2016 Mar. 7).

CMAJ 2016. DOI:10.1503/cmaj.1150093

CMAJ was just beginning to regain credibility with researchers following turbulent times a decade ago, and the recent "curious decisions" will necessitate restarting the process. ${ }^{1}$

It will take many years for $C M A J$ to regain its lustre, and while it is treading water, other leading journals will continue to pull ahead. The CMA will be rightly criticized for its myopic approach, which diminishes the stature of CMAJ and buffets it with the whims of seemingly unaccountable individuals. At a time when Canadian academic medicine is under substantial pressure, and there is a 
need for the CMA and CMAJ to take a leadership role, this is a deeply unfortunate own goal.

\section{Ordan J. Lehmann MD}

University of Alberta, Calgary, Alta.

\section{Reference}

1. Kelsall D, Patrick K, Stanbrook MB, et al. Upholding the integrity of your CMAJ. CMAJ 2016; 188:397.

CMAJ 2016. DOI:10.1503/cmaj.1150094

We write as concerned members of the CMA and as refugee health advocates in response to the recent dismissal of Dr. John Fletcher, editor-in-chief of CMAJ, as well as the Journal Oversight Committee. ${ }^{1}$ We realize that there are many issues that are likely at play here, and we clearly do not know or understand the complexity of the relationship between the CMA and CMAJ.

We have been impressed with both CMAJ and the CMA, because they have done their part in advocating in a respectful and professional manner for the rights of refugees in this country. The editorial by Stanbrook in 2014 was a brilliant piece that provided a crystal clear understanding to many members who perhaps did not fully comprehend the issues. ${ }^{2}$ CMAJ has used its news section to clarify important issues, such as the cuts to refugee health. We hope that the independence of the journal can be maintained to ensure transparency and integrity.

Refugee doctors in Canada were honoured to stand beside Dr. Chris Simpson who, as then president of the CMA, spoke at the news conference on Parliament Hill in 2015 in support of the need to rescind the cuts to the interim federal health program $;^{3}$ this has now come to fruition. In January 2016, the current president of the CMA, Dr. Cindy Forbes, joined us in Ottawa for a workshop on refugee health and spoke beautifully of the need for physicians to step up in the effort to provide care to the influx of Syrian refugees coming to Canada. She emphasized CMA's role in providing the needed resources and information for providers to do this job effectively.

We feel strongly that the CMA and $C M A J$ can and should come to terms with how to maintain the news section and the independent nature of the journal.

\section{Doug Gruner MD}

Department of Family Medicine, University of Ottawa, Bruyère Family

Health Team, Ottawa, Ont.

\section{Meb Rashid MD}

Crossroads Clinic, Women's College

Hospital, Toronto, Ont.

\section{Philip Berger MD}

Inner City Health Program, St. Michael's Hospital, Toronto, Ont.

\section{References}

1. Kelsall D, Patrick K, Stanbrook MB, et al. Upholding the integrity of your CMAJ. CMAJ 2016; 188:397.

2. Stanbrook MB. Canada owes refugees adequate health coverage. CMAJ 2014;186:91.

3. Rich P. Reinstate care for refugees, feds told. Available: https://www.cma.ca/En/Pages/reinstate-care -for-refugees-feds-told.aspx (accessed 2016. Mar. 9).

CMAJ 2016. DOI:10.1503/cmaj.1150095

As a Canadian physician, I am increasingly embarrassed. Undoubtedly, the firing of CMAJ's editor-in-chief and disbandment of the Journal Oversight Committee $^{1}$ is about money, not a falling reputation. ${ }^{2}$

$C M A J$ is a source of pride and has been ever since John Hoey's stewardship. In spite of what the CMA president or its executive may think, the journal has a sterling international reputation. To be guided by impact factors, (whatever they may be) is simply evidence of the CMA's insufficient knowledge of the complex world of medical publishing. Hence, I wonder why the onus for reform and so on falls on CMAJ rather than on the CMA leadership, especially given the history of its relationship with the journal.

I would be interested to learn whether the membership was consulted or informed about this decision before it was taken. If the membership was not part of this vital decision, perhaps the logical next step is not to focus on the journal and its stalwart hanging-in editors, but rather on the CMA itself.

\section{Ivan B. Pless MD}

McGill University, Montréal, Que.

\section{References}

1. Kelsall D, Patrick K, Stanbrook MB, et al. Upholding the integrity of your CMAJ. CMAJ 2016; 188:397.
2. CMA Board of Directors announces restructuring and modernization plan for CMAJ. Available: www.cma.ca/En/Pages/cma-board-of-directorsannounces-restructuring-and-modernization-planfor-the-cma-journal.aspx (accessed 2016 Mar. 7).

CMAJ 2016. DOI:10.1503/cmaj.1150096

I thought we had been through this in 2006, when the CMA fired Dr. John Hoey and resolved it would not happen again. ${ }^{1}$ For a time, I withdrew any contributions from CMAJ, including submissions and peer review, and encouraged colleagues not to support a journal that appeared to have been stripped of its editorial freedom.

Now the CMA Board, or whomever it takes instruction from, appears to have repeated its mistake. ${ }^{2}$

Our CMAJ helped pioneer reform in medical publishing through enhanced oversight and transparency of conflict of interest and mandatory clinical trial registration. With other small national medical journals in Croatia, Denmark and New Zealand, CMAJ exerted crucial influence in the international movement to increase truth and reduce distortions or outright lies in medical scientific publishing. Many courageous and insightful people have participated in this ongoing reform, but Canadian physicians and academics punch well above our weight.

What is wrong with a CMA Board that fails to recognize CMAJ's accomplishments? As the former Journal Oversight Committee members lament, why has the Board not learned from the past or Dick Pound's constructive criticism? ${ }^{3}$

I am astonished and disappointed that CMA leaders don't appear to feel any responsibility to communicate frankly with CMA members. Why was Dr. John Fletcher fired? Why was the Journal Oversight Committee dismissed?

The University of British Columbia has learned recently that avoiding questions about the mysterious firing of its president simply undermines confidence in the board and ensures that unresolved issues continue to simmer. Just because many CMA members don't bother to vote in Board elections does not mean it's OK for the board to rule by divine right.

From respect for CMAJ's remaining editors and the journal's accomplishments, I will continue to volun- 